Available online at GSC Online Press Directory

GSC Biological and Pharmaceutical Sciences

e-ISSN: 2581-3250, CODEN (USA): GBPSC2

Journal homepage: https://www.gsconlinepress.com/journals/gscbps

(RESEARCH ARTICLE)

\title{
Assessment of steviol on pro-inflammatory cytokines release in human CD14+ cells
}

\author{
Rattanasrisomporn Jatuporn ${ }^{1}$, Boonkaewwan Waraporn ${ }^{2}$, Kayan Autchara ${ }^{3}$ and Boonkaewwan Chaiwat ${ }^{3 *}$ \\ ${ }^{1}$ Department of Companion Animal Clinical Science, Faculty of Veterinary Medicine, Kasetsart University, Bangkok, \\ Thailand. \\ 2 Department of Preventive and Social Medicine, Faculty of Medicine, Srinakharinwirot University, Nakhonnayok, \\ Thailand. \\ ${ }^{3}$ Department of Animal Science, Faculty of Agriculture, Kasetsart University, Bangkok, Thailand.
}

Publication history: Received on 12 June 2018; revised on 23 July 2018; accepted on 25 July 2018

Article DOI: https://doi.org/10.30574/gscbps.2018.4.2.0048

\begin{abstract}
Steviol is a major metabolite of stevioside which is a natural noncaloric sweetener. The aim of this present study was to investigate an inhibitory activity of steviol on pro-inflammatory cytokines release from lipopolysaccharide (LPS)stimulated human $\mathrm{CD} 14^{+}$cells. $\mathrm{CD} 14^{+}$cells were incubated with different concentrations of steviol in the absence or presence of LPS. TNF- $\alpha$, IL-1 $\beta$ and IL- 6 level were determined by using human enzyme-linked immunosorbent assay (ELISA) kits. Steviol at the concentration of $1-100 \mu \mathrm{M}$ significantly inhibit $(\mathrm{P}<0.05)$ the release of TNF- $\alpha(966.0 \pm 66.0$, $906.3 \pm 36.7$ and $659.3+\underline{5} 2.3$ vs $1190.3+7 \underline{5} .5 \mathrm{pg} / \mathrm{ml})$ and $\mathrm{IL}-1 \beta\left(2834.0+67.2 \_2440.0+70.5\right.$ and $2181.3+143.3$ vs 3226.7 $+106.6 \mathrm{pg} / \mathrm{ml}$ ) in a dose dependent manner when compared to LPS-treated CD14+ cells. While the inhibition of IL-6 $(\mathrm{P}<0.05)$ was found at $10 \mu \mathrm{M}$ and $100 \mu \mathrm{M}(2171.7+4 \underline{4} .3$ and $1902.3+\underline{58.0}$ vs $2580.3+105.2 \mathrm{pg} / \mathrm{ml})$. In conclusion, steviol, a major metabolite of stevioside, possess an anti-inflammatory activity in human CD14 ${ }^{+}$cell.
\end{abstract}

Keywords: Steviol; TNF- $\alpha$; IL-1 $\beta$; IL-6; CD14+ cell

\section{Introduction}

Steviol (SVO) is an aglycone of stevioside which is a natural non-caloric sweetener isolated from Stevia rebaudiana Bertoni. Stevia leaves and its extracts, including stevioside, have traditionally been used as a sweetener to sweeten a variety of foods especially for those who suffering from obesity and diabetes mellitus [1]. Stevioside is degraded into steviol by the bacterial flora of the cecum [2]. Steviol, a major metabolite of stevioside, has a molecular weight of 318.44 Da with the chemical formula of $\mathrm{C}_{20} \mathrm{H}_{30} \mathrm{O}_{3}$. It is therefore the colonic cell line (Caco-2) was shown to absorb steviol but not stevioside [3].

Inflammatory process is triggered mainly by immune cells and it is involved with cytokines release [4]. CD14+ monocytes are immature phagocytic cells circulating in the blood that phagocytize and degrade microbes. Bacterial lipopolysaccharide (LPS) was shown to stimulate the immune cell to release pro-inflammatory cytokines such as TNF$\alpha$, IL-1 $\beta$ and IL-6[5]. The inhibition of pro-inflammatory cytokines can be used as a tool to determine anti-inflammatory activity of the natural products. Therefore, the aim of this study was to examine the effects of steviol, a major metabolite of stevioside, on anti-inflammatory activity using an in vitro model LPS-stimulated CD14+ cells.

\footnotetext{
${ }^{*}$ Corresponding author

E-mail address: agrcwb@ku.ac.th
}

Copyright (C) 2018 Author(s) retain the copyright of this article. This article is published under the terms of the Creative Commons Attribution Liscense 4.0. 


\section{Material and methods}

\subsection{Preparation steviol}

Crude stevioside was supplied by Thai Pharmacognosy Research Laboratory, Chaing Mai, Thailand. Steviol (approx. $90 \%$ purity) was obtained by oxidation of stevioside as described by Ogawa et al. (1980) [6]. Purity of steviol were determined by using High-performance liquid chromatography conducted with a Waters model 510 liquid chromatograph (Waters, Millipore Corp., Milford, MA).

\subsection{Isolation of peripheral blood mononuclear cells (PBMCs) and CD14+ cells preparation}

A $5 \mathrm{ml}$ of blood was kindly donated from healthy volunteers. Peripheral blood mononuclear cells (PBMC) were separated from blood samples according to the method described by Boyum (1968) [7]. CD14+ cells were removed from PBMC by using Dynabeads (M-450 CD14+; Dynal Inc., Oslo, Norway) according to the manufacturer's instruction. The Dynabeads-bound cells (CD14+ cells) were washed three times with phosphate-buffered saline (PBS). CD14 ${ }^{+}$cells were adjust to $1 \times 10^{6}$ cells $/ \mathrm{ml}$ and grown in RPMI 1640 medium containing $25 \mathrm{mM}$ HEPES, 2 mM L-glutamine (Sigma, St. Louis, MO, USA), 10\% heat inactivated fetal calf serum (Gibco BRL, USA), penicillin (100 U/ml) and streptomycin (100 $\mu \mathrm{g} / \mathrm{ml}$ ) in a humidified atmosphere of $5 \% \mathrm{CO}_{2}$ at $37{ }^{\circ} \mathrm{C}$.

\subsection{Cell viability assay}

To detect viability of cells, the method of Mosmann (1968) [8] using the MTT (3-(4, 5-dimethylthaizol-2-yl)-2, 5diphenyltetrazolium bromide) colorimetric assay was performed. In brief, CD $14^{+}$cells $\left(1 \times 10^{6}\right.$ cells $\left./ \mathrm{ml}\right)$ were incubated with varying concentrations of steviol in the absence or presence of LPS (1 $\mathrm{g} / \mathrm{ml}$ )(Sigma). Formazan dye was dissolved with dimethylsulfoxide (DMSO) and the absorbance of each well was measured at $540 \mathrm{~nm}$ in an automatic microplate reader (Wallac Victor 1420, Perkins Elmer).

\subsection{Pro-inflammatory cytokines determination}

CD14+ cells $\left(1 \times 10^{6}\right.$ cells $\left./ \mathrm{ml}\right)$ were seeded into a 96-well plate and incubated with different concentrations of steviol in the absence or presence of $\operatorname{LPS}(1 \mu \mathrm{g} / \mathrm{ml})$ for $24 \mathrm{~h}$ in a humidified atmosphere of $5 \% \mathrm{CO}_{2}$ at $37 \stackrel{\circ}{\circ}$ C. Supernatant fluids were collected and stored at $-80^{\circ} \mathrm{C}$ until pro-inflammatory cytokine was assayed by using a commercial human TNF- $\alpha$, IL-1 $\beta$ and IL-6 enzyme-linked immunosorbent assay (ELISA) kits (R\&D systems, Minneapolis, MN, USA).

\subsection{Statistical analysis}

Data from five individual experiments were analyzed and presented as mean \pm S.E.M. Statistical significance was determined by using one-way ANOVA and student Newman-Keuls, with a value of $p<0.05$ as being statistically significant.

\section{Results and discussion}

\subsection{Effect of steviol on cell viability}

To confirm non-toxic concentration of steviol in the determination of pro-inflammatory cytokines release, cytotoxic effects of steviol on CD14+ cells was determined by using MTT assay. This method has been widely used to monitor cell viability. The metabolic activity is measured in populations of cells by incubating the cells with a tetrazolium salt (MTT) that is cleaved into a colored formazan product by cellular metabolic activity [9]. Steviol, in doses ranging from $0.1-100$ $\mu \mathrm{M}$ had no cytotoxic effect in CD14+ cells. Cell viability was about $100 \%$ (Figure 1). Previous study in four intestinal cell lines (T84, HT29, Caco-2 and IEC-18 cells) investigated the effects of steviol on cell viability and reported that steviol at concentration of $0.1-100 \mu \mathrm{M}$ had no cytotoxic effect in T84, HT29, Caco-2 and IEC-18 cells. Moreover, steviol at higher concentrations, $0.2 \mathrm{mM}$ and $0.8 \mathrm{mM}$, decreased cell viability, cell viabilities were $80-90 \%$ and $7-34 \%$ respectively [10]. 


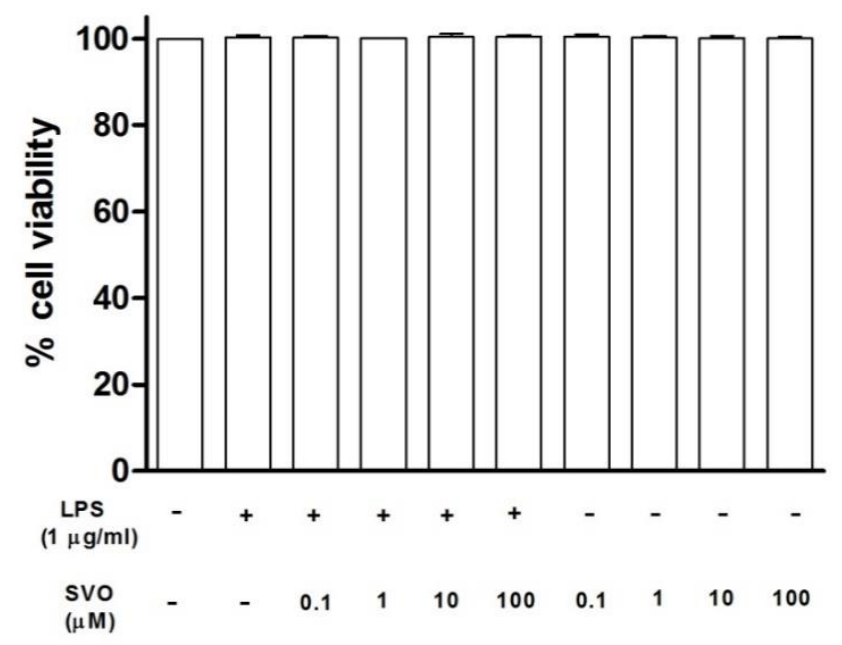

Figure 1 Cytotoxic effect of steviol (SVO) on CD14+ cells

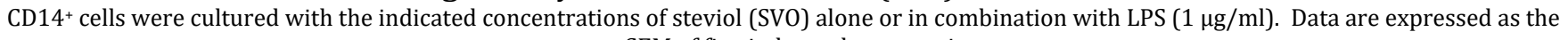
mean \pm SEM of five independent experiments.

\subsection{Effect of steviol on TNF- $\alpha$, IL-1 $\beta$ and IL- 6 release}

It is known that pathogenic bacteria can activate monocytes or macrophages directly, initiating a cytokine cascade in the inflammatory process and the immunological response [11]. Stimulated monocytes release a broad spectrum cytokines. TNF- $\alpha$, IL-1 $\beta$ and IL-6 are biologically active peptides produced by monocytes [12]. Thus, the interference in the production of TNF- $\alpha$, IL-1 $\beta$ and IL- 6 can be employed as criteria to evaluate anti-inflammatory effects. As shown in figure 2, level of TNF- $\alpha$ demonstrated a drastically increased when CD14+ cells were cultured with LPS $(1190.3 \pm 75.5$ $\mathrm{pg} / \mathrm{ml})$. In the absence of LPS, steviol itself $(0.1-100 \mu \mathrm{M})$ has no effect on TNF- $\alpha$ release. Interestingly, when CD14+ cells were cultured with steviol at concentration of 1-100 $\mu \mathrm{M}$ in the presence of LPS, the level of TNF- $\alpha$ was significantly decreased $(\mathrm{P}<0.05)$ in a dose dependent manner when compared to LPS-treated CD14+ cells $(966.0 \pm 66.0,906.3 \pm 36.7$ and $659.3 \pm 52.3$ vs. $1190.3 \pm 75.5 \mathrm{pg} / \mathrm{ml})$.

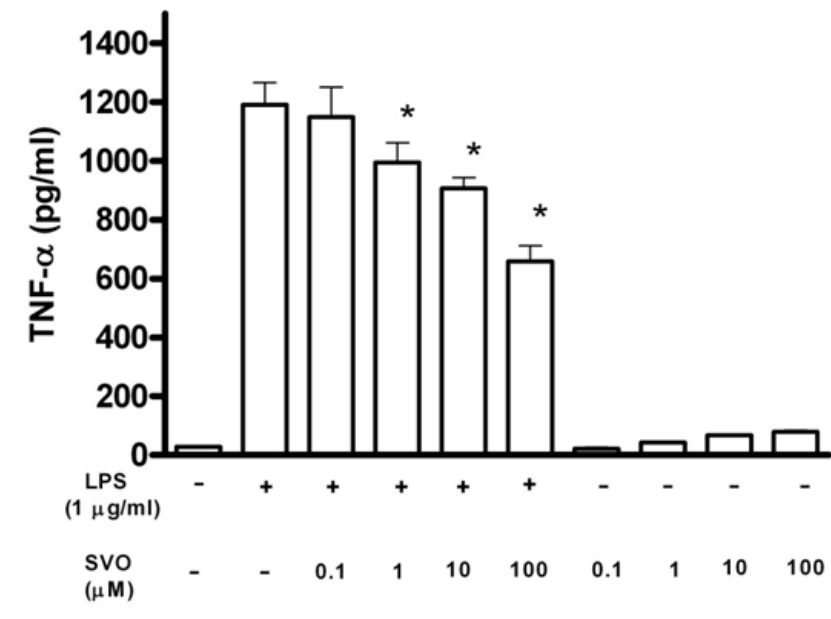

Figure 2 Effects of steviol on the production of TNF- $\alpha$

CD14+ cells were cultured with the indicated concentrations of steviol (SVO) alone or in combination with LPS (1 $\mu \mathrm{g} / \mathrm{ml})$. Data are expressed as the mean \pm SEM of five independent experiments. $(*)$ Statistically significant difference in cytokine release $(p<0.05)$, as compare with LPS-treated group.

Steviol at concentration of 0.1-100 $\mu \mathrm{M}$ has no effect on IL-1 $\beta$ release (Figure 3). LPS stimulated CD14+ cells resulted in an increase of IL-1 $\beta$ production $(3226.7 \pm 106.6 \mathrm{pg} / \mathrm{ml})$. Similarly to TNF-, when CD14+ cells were cultured with steviol $(1-100 \mu \mathrm{M})$ in the presence of LPS results demonstrated that IL-1 $\beta$ significantly decreased $(\mathrm{P}<0.05)$ when compared 
to LPS-treated CD14+ cells $(2834.0 \pm 67.2,2440.0 \pm 70.5$ and $2181.3 \pm 143.3 \mathrm{pg} / \mathrm{ml}$ vs. $3226.7 \pm 106.6 \mathrm{pg} / \mathrm{ml})(\mathrm{Figure}$ 3).

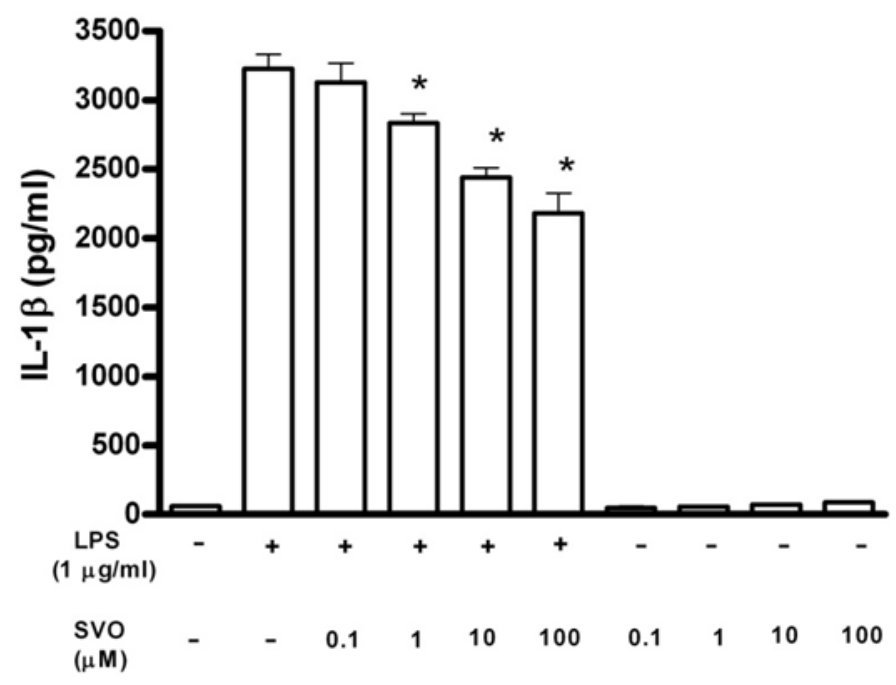

Figure 3 Effects of steviol on the production of IL-1 $\beta$

CD14 ${ }^{+}$cells were cultured with the indicated concentrations of steviol (SVO) alone or in combination with LPS (1 $\left.\mu \mathrm{g} / \mathrm{ml}\right)$. Data are expressed as the mean \pm SEM of five independent experiments. $\left({ }^{*}\right)$ Statistically significant difference in cytokine release $(\mathrm{p}<0.05)$, as compare with LPS-treated group.

As shown in figure 4, in the absence of LPS, steviol (0.1-100 $\mu \mathrm{M})$ has no effect on IL-6 release whereas the level of IL-6 was drastically increased in LPS stimulated CD14+ cells $(2580.3 \pm 105.2 \mathrm{pg} / \mathrm{ml})$. However, when CD14 ${ }^{+}$cells were cultured with steviol at concentration of $10 \mu \mathrm{M}$ and $100 \mu \mathrm{M}$ in the presence of LPS, IL-6 significantly decreased $(\mathrm{P}<0.05)$ in a dose dependent manner when compared to LPS-treated CD14+ cells $(2171.7 \pm 44.3$ and $1902.3 \pm 58.0$ $\mathrm{pg} / \mathrm{ml}$ vs. $2580.3 \pm 105.2 \mathrm{pg} / \mathrm{ml})$.

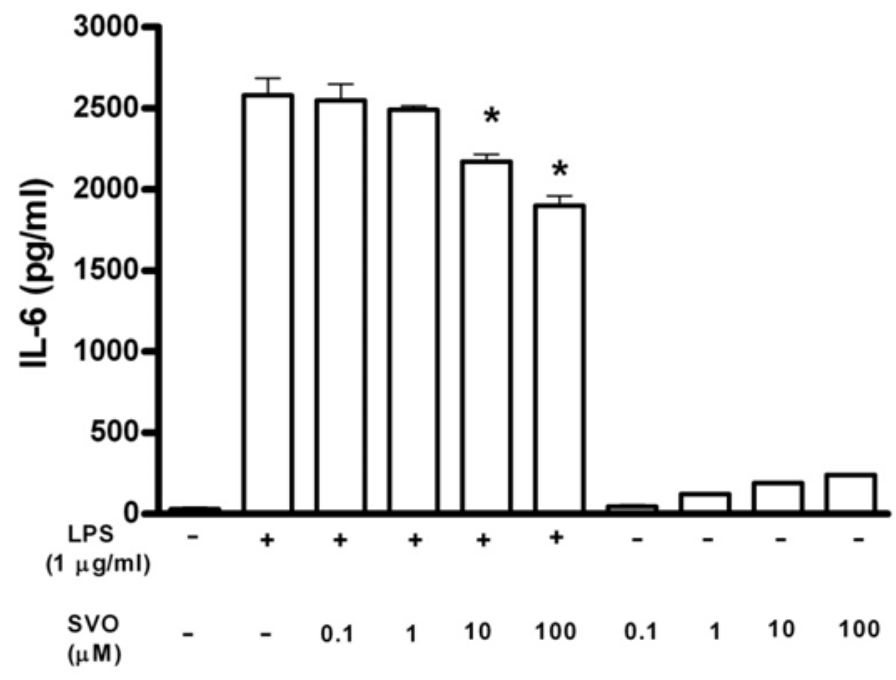

Figure 4 Effects of steviol on the production of IL-6

$\mathrm{CD} 14^{+}$cells were cultured with the indicated concentrations of steviol (SVO) alone or in combination with LPS (1 $\left.\mu \mathrm{g} / \mathrm{ml}\right)$. Data are expressed as the mean \pm SEM of five independent experiments. $(*)$ Statistically significant difference in cytokine release $(\mathrm{p}<0.05)$, as compare with LPS-treated group. 
Inflammatory cytokines are important for host defense mechanism from infection [13]. In this study, steviol alone (0.1$100 \mu \mathrm{M}$ ) had no effect on TNF- $\alpha$ IL-1 $\beta$ and IL-6 release (Figure 2-4). In addition, our results also demonstrated that steviol (1-100 $\mu \mathrm{M}$ ) significantly decreased the production of TNF- $\alpha$, IL-1 $\beta$ and IL-6 (Figure 2-4) in LPS-stimulated $\mathrm{CD} 14^{+}$cells cells. These activities were not attributed to cell cytotoxicity. These results are consistent with earlier observation of oral ingestion of stevioside that has an inhibitory effect on the release of TNF- $\alpha$ from LPS-stimulated PBMCs isolated from treated rats [14]. Since stevioside was degraded by normal flora in intestine to steviol [2]. Therefore, it is possible that the inhibitory effect on inflammatory cytokines release could be from the activity of this major metabolite, steviol.

\section{Conclusion}

The present study demonstrated that steviol at the concentration of 0.1-100 $\mu \mathrm{M}$ had no cytotoxic effect on CD14+ cells. In addition, steviol possess an inhibitory activity on pro-inflammatory cytokines release in CD14+ cells. Therefore, we can concluded that steviol has an anti-inflammatory activity.

\section{Compliance with ethical standards}

\section{Acknowledgments}

The authors would like to thank Professor Dr Chaivat Toskulkao for his valuable suggestions in this work.

\section{Disclosure of conflict of interest}

Rattanasrisomporn Jatuporn, Boonkaewwan Waraporn, Kayan Autchara and Boonkaewwan Chaiwat declare that they have no conflict of interest.

\section{References}

[1] Hanson JR and Oliveira BH. (1993). Stevioside and related sweet diterpenoid glycosides. National Product Report, 10, 301-309.

[2] Geuns JM, Augustijins P, Mols R, Buyse JG and Driessen B. (2003) Metabolism of stevioside in pigs and intestinal absorption characteristics of stevioside, rebaudioside A and steviol. Food and Chemical Toxicology, 41(11), 15991607.

[3] Koyama E, Sakai N, Ohori Y, Kitazawa K, Izawa O, Kakekawa K, Fujino A and Ui M. (2003). Absorption and metabolism of glycosidic sweeteners of stevia mixture and their aglycone, steviol, in rats and humans. Food and Chemical Toxicology, 41(3), 875-883.

[4] Moon PD, Jeong HJ, Um JY, Kim HM and Hong SH. (2007). LPS-induced inflammatory cytokine production was inhibited by Hyungbang Jihwang Tang through blockade of NF-kappaB in peripheral blood mononuclear cells. International Journal of Neuroscience, 117(9), 1315-1329.

[5] Bas E, Recio MC, Abdallah M, Manez S, Giner RM, Cerda-Nicolas M and Rios JL. (2007). Inhibition of the proinflammatory mediator production and anti-inflammatory effect of the iridoid scrovalentinoside. Journal of Ethnopharmacology, 110, 419-427.

[6] Ogawa T, Nozaki M and Mitsui M. (1980). Total synthesis of stevioside. Tetrahedron, 36, 2641-8.

[7] Boyum A. (1968). Isolation of mononuclear cells and granulocytes from human blood. Scandinavian Journal of Clinical and Laboratory Investigation, 21, 77-89.

[8] Mosmann T. (1983). Rapid colorimetric assay for cellular growth and survival: application to proliferation and cytotoxicity assays. Journal of Immunological Methods, 65(1-2), 55-63.

[9] Gorduysus M, Avcu N, Gorduysus 0, Pekel A, Baran Y, Avcu F and Ural AU. (2007). Cytotoxic effects of four different endodontic materials in humam periodontal ligament fibroblasts. Journal of Endodontics, 33(12), 14511454.

[10] Chaiwat B, Mei A, Chaivat T and Mrinalini CR. (2008). Specific immunomodulatory and secretory activities of stevioside and steviol in intestinal cells. Journal of Agricultural and Food Chemistry, 56 (10), 3777-3784.

[11] Buamann H and Gauldie J. (1994). The acute phase response. Immunology Today, 15, 74-89. 
[12] Morikawa K, Watabe H, Araake M and Morikawa S. (1996). Modulatory effect of antibiotics on cytokine production by human monocytes in vitro. Antimicrobial Agent and Chemotherapy, 4, 1366-1370.

[13] Glauser MP. (1996). The inflammatory cytokines: new developments in the pathophysiology and treatment of septic shock. Drugs; 52(2), 9-17.

[14] Jatuporn N, Narissara L, Autchara K and Chaiwat B. (2017). In vitro and in vivo assessment of inhibitory effect of stevioside on pro-inflammatory cytokines. Avicenna Journal of Phytomedicine, Avicenna Journal of Phytomedicine, 7(2), 101-106.

\section{How to cite this article}

Rattanasrisomporn J, Boonkaewwan W, Kayan A and Boonkaewwan C. (2018). Assessment of steviol on proinflammatory cytokines release in human CD14+ cells. GSC Biological and Pharmaceutical Sciences, 4(2), 37-42. 